\title{
レンネット・カゼインの配向性形成におよぼす $\mathrm{pH}$ の影響
}

\author{
菊池栄一 ${ }^{*} \cdot$ 小林秀行 ${ }^{* *} \cdot$ 日下部功 ${ }^{* *} \cdot$ 村上和雄 ${ }^{* *}$ \\ The Effect of $\mathrm{pH}$ on the Orientation of Rennet Casein \\ Eiichi KikUCH ${ }^{*}$, Hideyuki Kobayashi ${ }^{* *}$, Isao KuSAKaBE** \\ and Kazuo Murakami** \\ ${ }^{*}$ Research Division, Snow Brand Milk Products Co., Ltd. 13 Honshio-cho, \\ Shinjuku-ku, Tokyo 160 \\ ** Institute of Applied Biochemistry, University of Tsukuba 1-1-1 \\ Tennohdai Tsukuba-shi, Ibaraki 305
}

\begin{abstract}
A study on the effect of $\mathrm{pH}(4.5 \sim 6.8)$ was conducted to clarify the characteristics of the orientation behavior of rennet casein. As a result, the orientation of rennet casein was observed at $\mathrm{pH} 5.3 \sim 5.4$ after squeezing out the casein from a syringe by shear stress. A maximum pellet volume of rennet casein at $10^{\circ} \mathrm{C}$ was given at about $\mathrm{pH} 5.4$. On the other hand, calcium and phosphate in rennet casein tended to transfer to the serum at low $\mathrm{pH}$, but the degree of their transfers decreased gradually above pH 5.4. From the relation between the change of pellet volume and the shift of protein fraction to the serum, the maximum degree of hydration of rennet casein was observed at about pH 5.3 5.4. The phenomena of the orientation of rennet casein could be explained from the behavior of hydration of rennet casein and of the transfer of calcium and phosphate to the serum. (Received Jul. 24, 1987)
\end{abstract}

チーズの製造において，レンネット・カードの性状は 当然カードの構成単位であるカゼインの状態によって支 配される。乳カゼインは $\alpha_{\mathrm{s} 1}$-カゼイン, $\beta$-カゼイン,

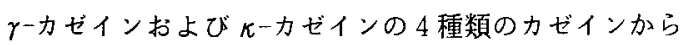
構成されておりり ${ }^{1)}, \alpha_{\mathrm{s} 1}$-カゼインと $\beta$-カゼインが主体 を占め，それぞれ約 55\%，30\%を占めている2゙.これ らのカゼインがカルシウムおよびリン酸と共に複合体を 構成してカゼイン・ミセルを形成している゙3.

このようなカゼインに，レンネットが作用すると，多 くのカゼイン同士が疑集し，更にカゼインの塊状体を形 成する.この塊状体を構成しているカぜインは，カルシ ウムを介して架橋し，脂肪をなかに抱き込みながら三次 元の網目構造をつくる.このカゼイン塊状体に圧縮, 押 出し, 引張り等を加えて変形を与えると, 配向して従来
の等方性のある塊状体から異方性のある塊状体に変化す ると考えられる.

“さける”特性を有するチーズは, カゼインにレンネ ットを添加して生じたカゼイン塊状体からホエイを排出 して得だカードを加熱，混練および延伸することにより 製造される.

さきに，KosIKowSKI ら ${ }^{15)}$ はモザレラチーズの製造 のなかで，カゼインがレンネットによってジカルシウム ・パラカゼイネートになり，更に生成される酸の作用に よってカルシウムの一部溶解がおこり，モノカルシウム ・パラカゼイネートになるといっている，このパラカゼ イネートを延伸すると糸ひき性のある形状を呈するとし ているが，その作用機作については明らかでない．

著者らは, レンネット・カゼインの配向性に注目し,

\footnotetext{
†担子菌産生凝乳酵菜の応用に関する研究

*雪印乳業株式会社 研究本部（勇160 東京都新宿区本塩町 13）

**筑波大学 応用生物化学系（テ 305 茨城県つくば市天王台 1-1-1）
} 
このカゼインの配向性におよぼす $\mathrm{pH}$ の影響を観察す るとともに，力ゼインの水和度の変化㧍よびカード中の カルシウムとリンの移行・割合について検討したので, その結果について述べる.

\section{実 験 方 法}

\section{1.レンネット・カゼイン試料溶夜の調製}

標準溶液を得るために，あらかじめクリス・ハンセン (CHRIS HANSEN) 社製の仔牛レンネットで調製したレ ンネット・カゼイン粉米を用いた，レンネット・カゼイ ン末 $100 \mathrm{~g}$ にクエン酸ナトリウム溶液（pH 3.0）を加 え, $200 \mathrm{ml}$ に定容後, 48 時間， $5^{\circ} \mathrm{C}$ で保持し，十分に レンネット・カゼインを溶解させた，更に， $400 \mathrm{~m} l$ に 定容後 $25 \mathrm{~m} l$ を採取し, 稀 $\mathrm{NaOH}$ 溶液で所定の $\mathrm{pH}$ に調製し， $100 \mathrm{ml}$ に起容し試料溶液として供した。

\section{2.レンネット・カゼインのペレット容積の測定}

日立分離用遠心機を用い，レンネット・カゼイン試料 溶液を遠心管に採取し，所定の濃度で 1 時間保持後 10 ${ }^{\circ} \mathrm{C}$ で $6 \times 10^{3} \mathrm{rpm}, 1$ 時間の遠心分離を行ない，遠心管 の底部に生じたレンネット・カゼインのペレットの重量 と比重を測定して、これよりぺレットの容積を算出した.

ペレットの比重は, ピクノメーターに採取したペレッ

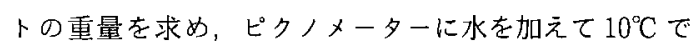
定容し，このときの全重量からペレットとピクノメータ 一の重量とを差し引いて加えた水の重量を知り，これを 容積に換算した。 ピクノメーターの容積から加えた水の 谷積を差し引いて, ペレットの谷積を求め,これより比 重を算出した。

\section{3. カルシウムの定量}

レンネット・カゼインの試料溶液を $550^{\circ} \mathrm{C}$ で灰化後,

$1 \mathrm{~N} \mathrm{HCl}$ で溶解し試料全体に含有されるカルシウムの 総量を求めた。 また，遠心分離後の上清に対して同様に 分析し， $\mathrm{pH}$ の差䔬により生ずるカルシウムの移行を測 定した，カルシウム定量は EDTA 逆滴定法" により行 った.

\section{4. リンの定量}

カルシウムと同じ試料を用い，ALLEN の方法で定量 した ${ }^{5)}$. リンの測定においては，日立分光光度計 100-10 型を用い $10 \times 10 \mathrm{~mm}$ 石英セルを使用して $720 \mathrm{~nm}$ の吸光度をはかることによって求めた、リン含量は $\mathrm{KH}_{2} \mathrm{PO}_{4}$ 溶液を標準物質として，同様に测定して得ら れたリン含量の検量線を用いて求めた。

\section{5. 上清タンパク質濃度の測定}

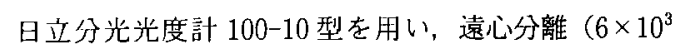

rpm）によって得られた上清側のタンパク質について 280 $\mathrm{nm}$ の吸光度を测定することによって求めた，尚，吸光 度 10 のとき,タンパク質濃度 $1 \%$ と規定した。

\section{6. 濁度の測定}

日立分光光度計 100-10型を用い, 波長 $350 \mathrm{~nm}$ にお ける吸光度 $\ln \left(I_{0} / I\right)$ の值をむって濁度とした。

\section{実 験 結 果}

\section{1.レンネット・カゼインの配向性に関する定性的観 察}

$\mathrm{pH} 4.5$ から $\mathrm{pH} 6.8$ にわたって各 $\mathrm{pH}$ に調節したレ ンネット・カゼイン溶液を恒温調節器内において $48^{\circ} \mathrm{C}$, 1 時間保持した後遠心分離をして沈殿部を得た。この沈 殿部を特殊ノズル（基底部内径 $\phi_{1}=3.5 \mathrm{~mm}$ ，先端部 内径 $\phi_{2}=1.5 \mathrm{~mm}$ ，長さ $15 \mathrm{~mm}$ ）を装着したパイレッ クス製シリンジ（円筒内径 $\phi_{0}=18 \mathrm{~mm}$, 長さ $100 \mathrm{~mm}$ ) 中に移した後， $10^{\circ} \mathrm{C}$ の水中に圧縮押出しを行った。こ の際の沈殿部中の固形濃度（無水物換算）は，約 $30 \%$ (重量)である。

観察結果を Table 1 に示した。これからわかるよう に, pH 5.3〜 5.4 において弾性のある糸状組織物が得 られたが, pH 5.2 以下ではカゼイン沈殿部の配向性を 有する系状組織物の形成は認められなかった。

$\mathrm{pH} 5.6$ 以上では，系状のゲル状組織物は徐々に透明 さを增し，時間ととすに流動し易いペースト状の傾向を 示した。

2. レンネット・カゼインのペレット容積およびタン パク質移行度におよぼす $\mathrm{pH}$ の影慣

$\mathrm{pH} 4.5$ から $\mathrm{pH} 6.8$ にわたる試料を $10^{\circ} \mathrm{C}$ に 1 時間 保持した後, 同温度で 1 時間遠心分離して遠沈管底部に

Table 1 Qualitative observation of the orientation of rennet casein

\begin{tabular}{ccc}
\hline $\mathrm{pH}$ & $\begin{array}{c}\text { Observation with } \\
\text { the syringe } \\
\text { at } 35^{\circ} \mathrm{C}\end{array}$ & $\begin{array}{c}\text { Observation with } \\
\text { the syringe } \\
\text { at } 45^{\circ} \mathrm{C}\end{array}$ \\
\hline $4.5 \sim 5.0$ & $\times$ & $\times$ \\
5.2 & $\triangle$ & $\triangle$ \\
$5.3 \sim 5.4$ & $\bigcirc$ & $\bigcirc$ \\
5.6 & $\times$ & $\times$ \\
5.9 & $\times$ & $\times$ \\
$6.0 \sim 6.8$ & $\times$ & $\times$ \\
\hline
\end{tabular}

$x$ : isotropic structure

$\triangle$ : intermediate structure

(O) : anisotropic structure 
生じたカゼインの容積を算出した．その結果を Fig. 1 に示した. pH 5.4 付近においてカゼインは粘弾性のあ る密な状態となり，ペレット容積は最大に近づく．これ により $\mathrm{pH}$ が低下するとむしろ減少する， $\mathrm{pH}$ を上昇 させると徐々にゲル状に変化し，少し透明感を帯びたぜ リ一状に近づき容積の増加は横ばい傾向となる， $\mathrm{pH} 6.4$ では全体量に対するペレットの容積分率は $25 \%$ 程度で あったが，pH5.2 では17\% 位まで低下した。

更に，遠心分離後の上清側のタンパク質濃度を，280 $\mathrm{nm}$ における吸収測定から求め，これを Fig. 1 の右側 に示した. $\mathrm{pH} 5.4$ 付近までは上清側へのタンパク質の 移行は少ないが, 更に $\mathrm{pH}$ の上昇に伴い移行度が進行 する.一方, $\mathrm{pH} 5.4$ 以下の低い方では，上清タンパク 質濃度の変化は顕著に認められなかった。

以上のことから， pH 5.4 付近では容積変化が大きく， かつ上清タンパク質濃度の低い範囲にあることが判明し た、即ち、この範囲では水和度の高いレンネット・カゼ インの回収率の高い状態にあると考えられる.

3. $\mathrm{pH}$ の上昇に伴うカルシウムおよびリン濃度の変 化

$\mathrm{pH} 4.5 \sim \mathrm{pH} 6.8$ の試料を $10^{\circ} \mathrm{C} ， 1$ 時間保持し，遠心 分離後上清中に移行したカルシウム量を測定した。この 移行量を全カルシウム量から控除してペレット中のカル シウム量を算出した. その結果は Fig. 2 に示す通りで ある. 同様にして，上清側に移行したリン含量を測定し， 全リン量からこれを控除してペレット中のリン量とした

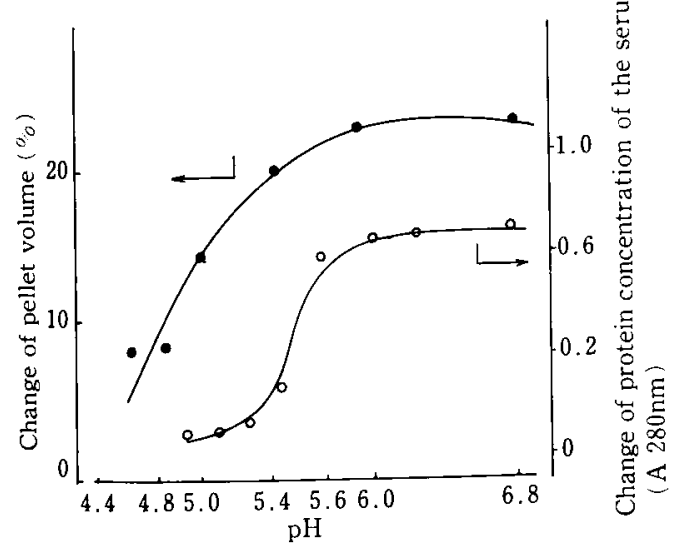

Fig. 1 The effect of $\mathrm{pH}$ on the pellet volume and the amount of protein transfered to the serum
(Fig. 3).Fig. 2 および Fig. 3 から， pH 5.3〜5.4 ではカゼインに付着していたカルシウム量は上清側に移 行をはじめる.リンについても，pH5.3〜 5.4 付近を 境に酸性側にすすむに伴い移行していくことを示してい 万.

一般に, カゼインミセルのカルシウムは, リン酸基や カルボキシル基と結合してミセル内に保持されていると 考えられている(6) 。 リン酸基やカルボキシル基の負荷電が減少し，カルシウ ムとの結合が解かれることによって，上清側への移行が 進行したものといえる。

\section{4. カルシウム/リン比率と $\mathrm{pH}$ との関係}

ペレット側のカゼインに含有するカルシウム/リンの 比率が $\mathrm{pH}$ の変化によってどのようにかわるかをみた。 縦軸にカルシウム/リン（mM ratio）を横軸に $\mathrm{pH}$ を とって，その関係をみたのが Fig. 4 である.

この図からわかるように，pH 5.3〜 5.4 付近にひと つの変移点がみられる. $\mathrm{pH} 5.3$ 以下では，カルシゥム/ リン比率は 9.0 以上となるが，その比率は横這い傾向を たよ゙る. $\mathrm{pH} 5.4 \sim \mathrm{pH} 5.8$ の間は一定の比率で急速な変 化を示し，離脱，吸着の激しいことを示唆している。 $\mathrm{pH} 5.8$ 以上ではカルシウム/リン比率は 7.0 以下とな

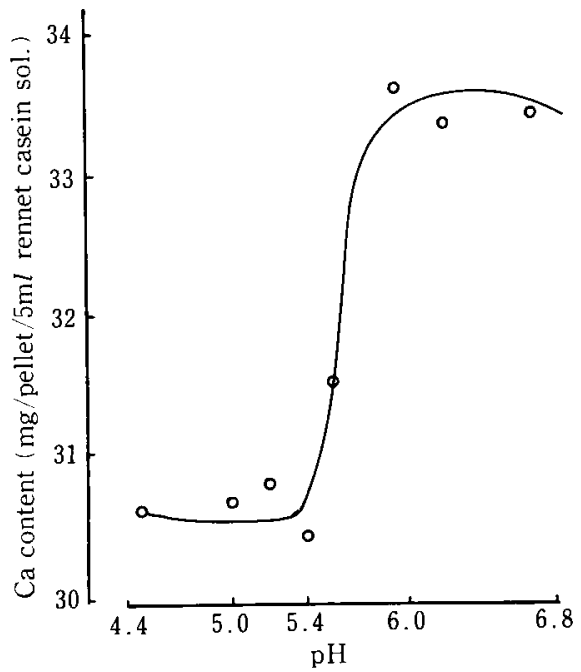

Fig. 2 The effect of $\mathrm{pH}$ on the $\mathrm{Ca}$ content in casein pellet

(The value in the pellet was calculated from the quantity of $\mathrm{Ca}$ which moved from the pellet to the serum.) 
り緩慢なカーブとなる. pH 5.3〜 5.4 付近は, リンの 移動よりカルシウムの移動が優勢となり，その比率の最 も高くなった終末点と見なされる。

\section{5. レンネット・カゼインの形態と $\mathrm{pH}$ との関係}

上述で得られたレンネット・カゼインのカルシウム/ リン比率のデー夕拉よび 2 項で得られたカゼインの水和 度を意味するペレット容積の変化との比較検討から，レ ンネット・カゼインの $\mathrm{pH}$ による形態的变化は，つぎ の3つに大別される。すすなわち，

$\mathrm{A}$ 領域では，イ）カルシゥム離脱が緩慢であるカル シゥム/リン比率 9.0 以上で，口）カゼインの水和度が 小さい ( $\mathrm{pH} 5.2$ 以下).

$\mathrm{B}$ 領域では，イ）カルシゥム，リンの離脱が一定の 割合で進行し，カルシゥム/リン比率 9.0 7.0 の範囲 で、口）カゼインの水和度が最大になる $(\mathrm{pH} 5.2 \sim \mathrm{pH}$ 5.7).

$\mathrm{C}$ 領域では，1）カルシゥムはむしろ取り込まれる 傾向となり，カルシゥム/リン比率 7.0 以下で，口）力 ゼインの水和度は平衡に達する( $\mathrm{pH}$ 5.8 以上).

これらのなかで，配向可能なレンネット・カゼインの 形態は B 領域の範ちゅうに属し,さきにおこなったシ リンジ式ノズルから得られた糸状組織物の形成する結果 上よく一致する.

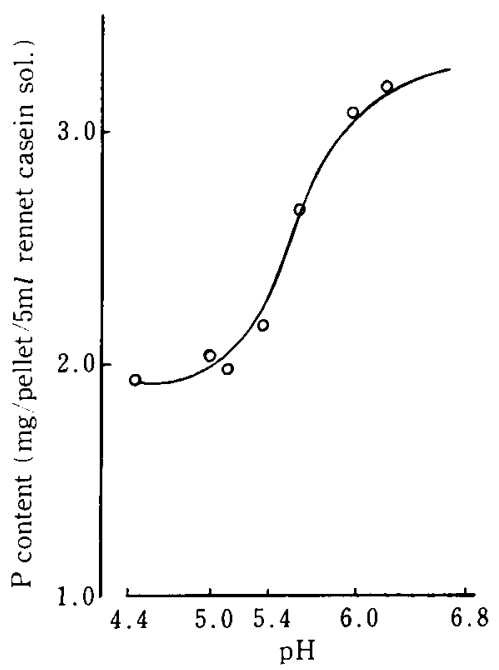

Fig. 3 The effect of $\mathrm{pH}$ on the phosphate content in casein pellet

(The value in the pellet was calculated from the quantity of phosphate which moved from the pellet to the serum.)

\section{考察}

レンネット・カゼイン溶液が，外的条件特に $\mathrm{pH}$ の 変化に対応して起こす変化を観察し，その機構を考察し レンネット・カゼインに関する基礎的知見を得ることに より，乳加工上の諸問題の解決に寄与しょうとするもの である。

特にチーズの製造に際し，レンネット・カゼインの性 状は $\mathrm{pH}$ の変化によって大きく左右される，この $\mathrm{pH}$ の変化によって起こるペレット容積の変化, タンパク質 の溶出, カルシウム, リンの挙動等を勘案し, 更にこれ らの結果をもとにカゼインの水和とカルシゥム, リンの 離脱割合の両者を関連させながら，カゼインの配向性に ついて検討を加えた。

レンネット・カゼイン末は, 凝乳酵素によって ゼインからパラーんーカゼインに変化しており，これを乾 燥したものである，これを緩衡液で還元した溶液を $\mathrm{pH}$

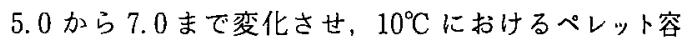
積の変化をみた。ペレット容積は $\mathrm{pH}$ の低い方では小 さいが, $\mathrm{pH}$ を上げていくに従って増加し， $\mathrm{pH} 5.4$ か ら5.6 付近を境にして横ばいの傾向に入る. pH 5.4 付 近を中心としたペレット容積のピークは, SNOEREN $ら^{10)}$ によるカゼインの容媒和の結果と近似している. また，VAN HOOYDONK ら ンの一部 $\beta$-カゼインが解離するとしているが，著者ら の $\mathrm{pH} 5.6$ の上清液にレンネットを加えると濁度が堌加

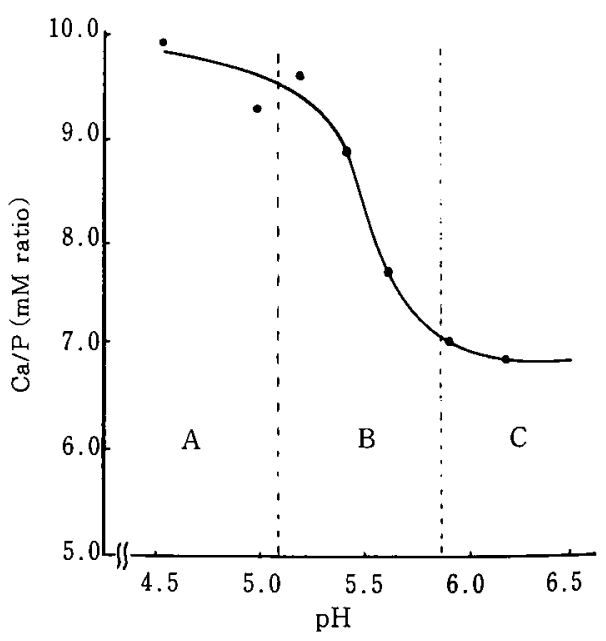

Fig. 4 The relationship between $\mathrm{Ca} / \mathrm{P}$ ratio and $\mathrm{pH}$ on casein pellet formation 
する事実とも符合している。

これらの事実から，カゼインは $\mathrm{pH}$ の少し高い方て 水和，溶解が進行し， pH が低下するとともに会合，収 縮の傾向をたどることが示唆された， $\mathrm{pH} 5.4$ 付近のペ レット容積のピークは，水和したカゼインのゆるい会合 であり，pH 5.4 から低下するに伴ない容積減少がみら れるのは，カゼインの密な収縮にはいったためと考えら れる.

カルシウムは $\mathrm{pH}$ の低下ととあに，上清側に移行す る割合が増加し，ペレット側から上清側へカルシウム溶 出が進行している．カゼインの会合には，カルシウムの 離脱之深く関係している ${ }^{12)}$ ．また，カルシウムの離脱は 溶媒の $\mathrm{pH}$ ，イオン強度によって大きく支配されると言 われている(13)14). 即ち、レンネット・カゼイン溶液に塩 化カルシウムを添加することによって、レンネット・カ ゼインは，酸性側で会合しやすくなる（Fig. 5)，この 事実は, カゼインの会合はカルシウムの離脱と密接に関 係していることを裏付けている.

$\mathrm{pH} 5.6$ から酸性側に移行すると, $\mathrm{pH} 5.4$ 付近で力 ゼインの水和度が高く，タンパク質の溶出の少ない状態 がみられる.この状態においては，カゼイン表面の負荷 電の隇少, ミセル間の静電的反発が小さくなってカゼイ ンの会合がすすみ，更にカルシウムの離脱によって一層 密に重合した塊状体になったものと推察される.

一方， $\mathrm{pH}$ をアルカリ側に移行させた場合，カゼイン 内のリン酸基，カルボキシル基によって，カルシウムな

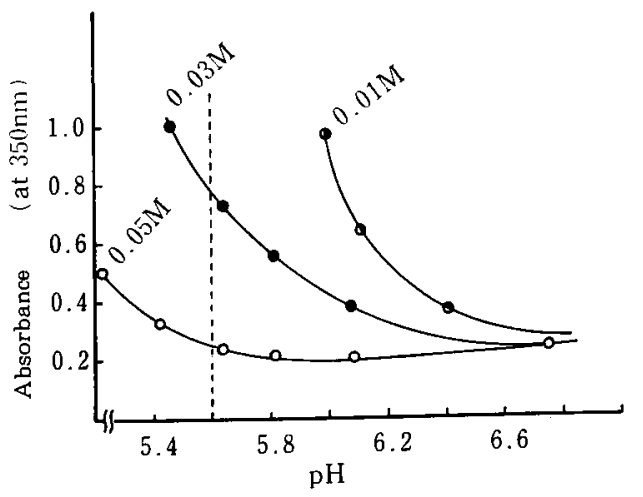

Fig. 5 Effect of $\mathrm{CaCl}_{2}$ concentration on aggregation of rennet casein at various $\mathrm{pH}$

(Aggregation of rennet casein was observed by measuring absorbance at 350 $\mathrm{nm}$.)
どは内部に抱き込ま狆ていく結果となったといえる， $\mathrm{pH}$ 6.0 以上のアルカリ側では，更にカルシゥムのカゼイン 内増加等の影響加らルーズな構造となり, 変化し易い状 態になるとみられる.

以上のことから，レンネット・カゼイン溶液を $\mathrm{pH} 4.5$ 〜 pH 6.8 の範囲においてシリンジ式ノズルにより圧縮 押出しをはかると, $\mathrm{pH} 5.4$ 付近でカゼインは配向性を むった糸状組織物となる。この $\mathrm{pH}$ 範囲におけるレン ネット・カゼインは，イ）カゼイン・ミセルに近似した 性質を一部保有しながら, 水和度の高い, 会合し易い状 態にある.ロ）カルシゥムの離脱に伴いカゼイン内の構 造は変化し易い形にある.このような状態下で押出しに よるずり応力を加えると，レンネット・カゼインははじ めて配向し易い状態になると推察される.

\section{要約}

pH 4.5 加ら pH6.8の範囲におけるレンネット・カ ゼイン溶液（濃度約 $30 \%$ ）に，シリンジ式ノズルを用 いて一種のずり応力を与えると, pH 5.3 5.4 付近に おいて配向性をもった糸状組織物が得られた。この現象 から、レンネット・カゼインの配向性におよぼす $\mathrm{pH}$ の影響を検討した。

1） $\mathrm{pH} 4.5$ から $\mathrm{pH} 6.8$ の範囲にわたるレンネッ ト・カゼインの容積変化と上清側へのタンパク質画分の 移行度との関係から，レンネット・カゼインの水和度の 最む大きいところは, pH5.3〜 5.4 付近である.

ロ）レンネット・カゼイン中のカルシウム/リンの比 率执よび水和度を表わすぺレット容積の変化から、レン ネット・カゼインの $\mathrm{pH} に よ る$ 形態的変化は $\mathrm{A}, \mathrm{B}, \mathrm{C}$ の3領域に大別される.

八）上記の B 領域の範囲に入る $\mathrm{pH} 5.4$ 以上からア ルカリ側に進むに従って, カルシウムおよびリンの上清 部への移行は減少する。

二）レンネット・カゼインの配向性は, カゼインの 水和度が高く，カゼインからのカルシウム, リンの離脱 の終末点に相当する $\mathrm{pH} 5.3 \sim 5.4$ とよく一致する.

\section{文献}

1) McKenzie, H.A.: Milk Proteins. 2, 87 (Academic Press Inc.) (1971).

2) Davies, D.T. and LAw, A.J.R. : J. Dairy Res., 44, 447 (1977).

3) McMeckin, T.L. and Groves, M.L. : Fundamentals of Dairy Chemistry, ed. Byron H. WebB and Arnold H. Johnson, 
P. 384 (The AVI Publishing Co., Inc.) (1965).

4) Kamel, T.H.: J. Agr. Food Chem., 8, 156 (1960).

5) Allen, R.J.L.: Biochem. J., 34, 858 (1940).

6) Ford, T.F., RAMSDell, G.A. and LANDSMAN, S.G. : J. Dairy Sci., 38, 843 (1955).

7) Ter, H. and Maria, G. : Neth. Milk Dairy J., 17, 185 (1963).

8) Burg, P.: Neth. Milk Dairy J., 1, 69 (1947).

9) Pyne, G.T. and McGann, T.C.A.: $J$. Dairy Res., 27, 9 (1960).

10) Snoeren, T.H.M., KloK, H.J., Van HoOYDONK, A.C.M. and DAMMAN, A.J.: Milch- wissenschaft, 36, 461 (1984).

11) Van Hooydonk, A.C.M., Hagedoorn, H.G. and Boerrigter, I.J.: Neth. Milk Dairy J., 40, 281 (1986).

12) Waugh, D.F., Statery, C.W. and CreaMER, L.K. : Biochemistry, 10, 817 (1971).

13) Thompson, M.P., Gordon, W.G., Boswell, R.T. and FARRELl Jr, H.M. : J. Dairy Sci., 52, 1161 (1969).

14) Payens, T.A.J.: J. Dairy Sci., 49, 1317 (1966).

15) Kosıkowski, F.V.: Mozzarella cheese. In "Cheese and Fermented Milk Foods" published by Kosikowski, F.V. and Associates, Brooktondale, New York. (1977).

(昭和 62 年 7 月 24 日 受理) 